Southwest Asia 


\section{Latinidad}

\section{Transnational Cultures in the United States}

This series publishes books that deepen and expand our understanding of Latina/o populations, especially in the context of their transnational relationships within the Americas. Focusing on borders and boundarycrossings, broadly conceived, the series is committed to publishing scholarship in history, film and media, literary and cultural studies, public policy, economics, sociology, and anthropology. Inspired by interdisciplinary approaches, methods, and theories developed out of the study of transborder lives, cultures, and experiences, these titles enrich our understanding of transnational dynamics.

Matt Garcia, Series Editor, Arizona State University, School of Historical, Philosophical, and Religious Studies; and Director of Comparative Border Studies

For a list of titles in the series, see the last page of this book. 


\title{
Southwest Asia
}

\author{
THE TRANSPACIFIC \\ GEOGRAPHIES OF CHICANA/O
}

LITERATURE

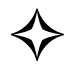

Jayson Gonzales Sae-Saue

RUTGERS UNIVERSITY PRESS

New Brunswick, New Jersey, and London 
Library of Congress Cataloging-in-Publication Data Names: Sae-Saue, Jayson Ty Gonzales, author.

Title: Southwest Asia : the transpacific geographies of Chicana/o literature/ Jayson Gonzales Sae-Saue.

Description: New Brunswick, New Jersey : Rutgers University Press, [2016] | Series:

Latinidad: transnational cultures in the United States | Includes bibliographical references and index.

Identifiers: LCCN 2015035673| ISBN 9780813577173 (hardcover : alk. paper) | ISBN 9780813577166 (pbk. : alk. paper) | ISBN 9780813577180 (e-book (epub)) | ISBN 9780813577197 (e-book (web pdf))

Subjects: LCSH: American literature-Mexican American authors-History and criticism. | Mexican Americans-Asia. | Internationalism in literature.

Classification: LCC PS153.M4 S235 2016 | DDC 810.9/86872-dc23

LC record available at http://lccn.loc.gov/2015035673

A British Cataloging-in-Publication record for this book is available from the British Library.

Excerpts from Korean Love Songs from Klail City Death Trip by Rolando Hinojosa reprinted courtesy of the author.

\section{Copyright $\odot 2016$ by Jayson Ty Gonzales Sae-Saue}

All rights reserved

No part of this book may be reproduced or utilized in any form or by any means, electronic or mechanical, or by any information storage and retrieval system, without written

permission from the publisher. Please contact Rutgers University Press, 106 Somerset Street, New Brunswick, NJ 08901. The only exception to this prohibition is "fair use" as defined by U.S. copyright law.

Visit our website: http://rutgerspress.rutgers.edu

Manufactured in the United States of America 
For my family-from all over the globe 
